\title{
' $Y$ ' split of the outer plexiform layer: an optical coherence tomography illusion!
}

\author{
Srikanta Kumar Padhy (다, ${ }^{1}$ Anup Kelgaonkar 다, ${ }^{2}$ Ashish Khalsa, ${ }^{2}$ Suman Sahu (i) ${ }^{1}$
}

${ }^{1}$ Ophthalmology, LV Prasad Eye Institute Bhubaneswar Campus, Bhubaneswar, Odisha, India ${ }^{2}$ Vitreo-Retina, LV Prasad Eye Institute Bhubaneswar Campus, Bhubaneshwar, Odisha, India

\section{Correspondence to Dr Anup Kelgaonkar; anupnk2008@gmail.com}

Accepted 26 March 2021

\section{DESCRIPTION}

We here in report an interesting optical coherence tomography (OCT) observation in two different eyes. First case represents a 26-year-old man, with a history of tobacco chewing for 8 years, presented with sudden onset of scotoma in his right eye for 1 week. The uncorrected visual acuity was 20/40 in right eye (OD) and 20/20 in left eye (OS), respectively. Anterior segment was essentially within normal limits. Right eye fundus examination revealed a dull foveal reflex with neurosensory detachment and subretinal fibrin features suggestive of central serous chorioretinopathy. OCT of OD passing through macula confirmed presence of a neurosensory detachment with subretinal hyperreflective material. On a closer look we could appreciate a ' $\mathrm{Y}$ ' split of the outer plexiform layer (OPL) (figure 1A, A1 and A2). Case 2 represents a 33-year-old woman who presented to us with recent onset metamorphopsia in her left eye for 2 days.
Best corrected visual acuity was 20/20 and 20/400 in OD and OS, respectively. Anterior segment was unremarkable under slit lamp. Dilated fundus examination revealed subretinal greyish membrane with speck of haemorrhage adjacent to it, suggestive of choroidal neovascular membrane which was confirmed with OCT and fundus fluorescein angiography. Similar to the first case, we also observed a 'Y' split of the OPL in the horizontal scan of the macular OCT (figure 1B, B1 and B2).

The OPL of human retina entails a dense network of synapses between dendrites of horizontal cells located in the inner nuclear layer and bipolar cells with inner segments of rods and cones from the outer nuclear layer (ONL). ${ }^{12}$ The outer two-thirds consisting of photoreceptors and surrounding muller cells constitutes the Henle fibre layer (HFL). Images from OCT are not derived purely from the anatomical structures present but rather rest on the optical properties of the tissues being imaged

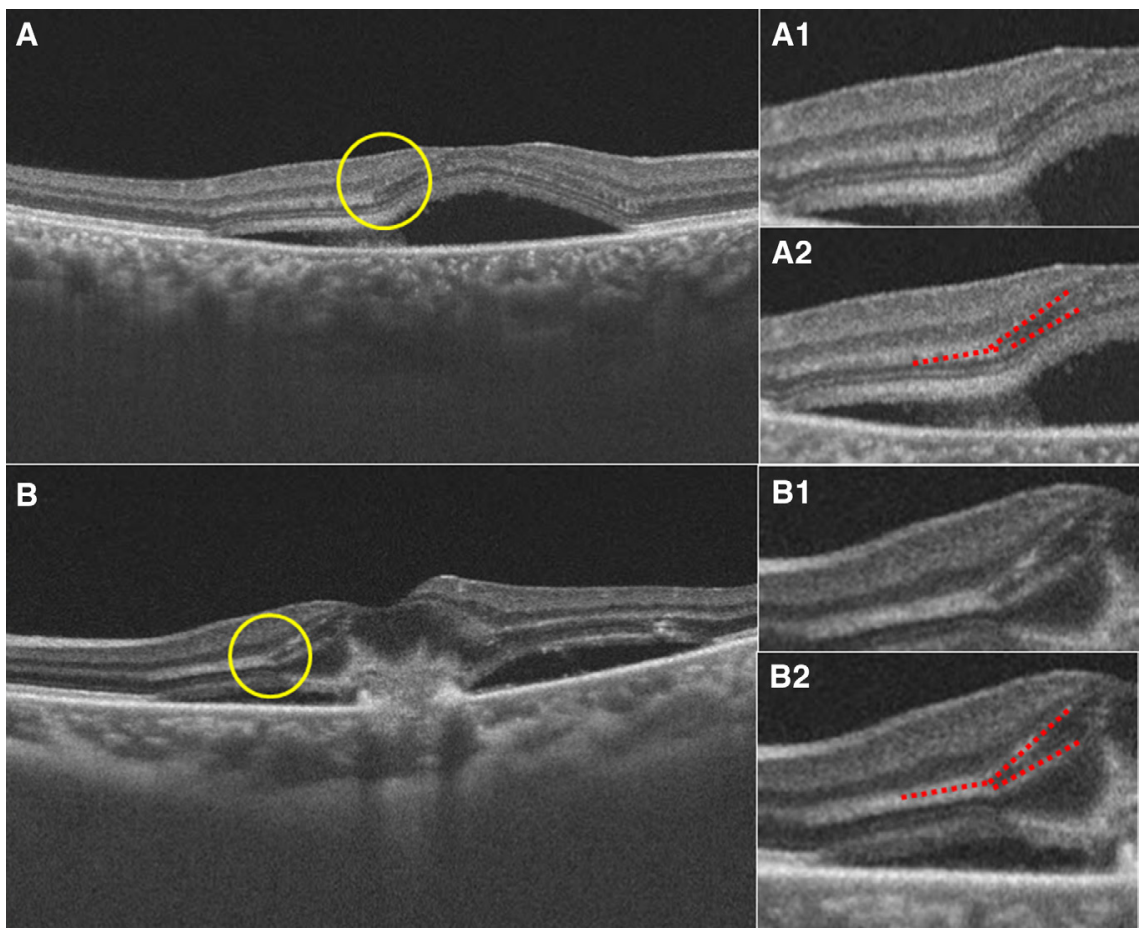

(c) BMJ Publishing Group Limited 2021. No commercial re-use. See rights and permissions. Published by BMJ.

\begin{tabular}{|l|}
\hline To cite: Padhy SK, \\
Kelgaonkar A, Khalsa A, \\
et al. BMJ Case Rep \\
2021;14:e242117. \\
doi:10.1136/bcr-2021- \\
242117 \\
\hline
\end{tabular}

Figure 1 Swept source optical coherence tomography horizontal scan passing through macula of (A) case 1 right eye reveals neurosensory detachment with subretinal hyper-reflectivity. It also shows the continuous hyper-reflective outer plexiform layer (OPL) band that has been separated in to two distinct thin bands separated by a hyporeflective zone (yellow circle), A1 and A2 (with dotted red lines) represent the magnified outlined area of split; (B) case 2 left eye reveals presence of hyper-reflective tentacle like lesion located entirely above the retinal pigmented epithelium along with disruption of retinal layers and subjacent neurosensory detachment. On closer look the hyper-reflective OPL band is noted to be split in to two thin bands separated by a hyporeflective zone (yellow circle), B1 and B2 (with dotted red lines) represent the magnified outlined area of split. 
and this property has been studied particularly while imaging Henle fibre layer. The key factor for these optical changes of HFL reflectivity is attributable to its oblique orientation in the normal retina. So, both Otani et $a l^{3}$ and Lujan et $a l^{4}$ reported

\section{Patient's perspective}

Patient 1: I consulted eye hospital for drop in vision in my right eye. I was diagnosed to have central serous chorioretinopathy. Doctors also informed me that on my OCT scan they noted accumulation of fluid underneath retina. I was suggested multiple life style modifications to help relieve my ocular condition. I was advised to avoid tobacco chewing which had been my practise since past 8-10 years. I was also advised to take adequate sleep at night.

Patient 2: I developed severe and sudden loss of vision in my left eye. On consultation in retina OPD, I was told that I had choroidal neovascularisation in my left eye. I was told that this clinical observation of my treating doctor was confirmed with optical coherence tomography and fundus fluorescein angiography. After these imaging studies, doctors conveyed me that the cause of this condition was idiopathic meaning something that either did not have any specific causation or there is an undifferentiated causality. I was also advised to have injection inside my eye to decrease the fluid causing swelling inside my retina due to choroidal neovascular membrane. I was told that, multiple injections are required for this condition and the final visual outcome is often subnormal vision due to scarring.

\section{Learning points}

- ' $Y$ ' shaped split can be seen on swept source optical coherence tomography in outer plexiform layer when central macula is elevated either due to serous or solid elevation.

- It is an artefact or optical illusion and should not be confused with intraretinal fluid, cystic changes, intraretinal or subretinal septae.

- Observation of this finding requires no change in management of primary pathology. However, knowledge of this entity is necessary to avoid misdiagnosis or treatment. that by purposefully entering the pupil through an eccentric position and making it more perpendicular to the cells, HFL can be imaged reproducibly and distinctly in OCT. Similar enhancement of the OPL can also be done by altering the gaze of the subjects. We here report an interesting observation: ' $\mathrm{Y}$ ' split of OPL; noted on swept source OCT in eyes with elevated macula secondary to serous or solid neurosensory macular detachments. The inner one-third of the OPL was hyper-reflective compared with the ONL, whereas HFL had similar reflectivity as that of ONL, however, with a hyper-reflective outer boundary. The OCT images reveal as if the continuous hyper-reflective OPL band has been separated into two distinct thin bands separated by a hyporeflective zone (hyper-reflectivity turns into hyporeflectivity at the angle point), a tomographic illusion which is an optical phenomenon. This appearance is due to the oblique orientation of the elevated retina (neurosensory detachment) with respect to the incident light even in primary gaze and normal position. Ouyang et $\mathrm{al}^{5}$ has described six different phenotypes of the OPL on OCT. To conclude, identification of this optical illusion carries vital importance for treating ophthalmologists and optometrists while interpreting or reporting an OCT.

Contributors SKP, AKelgaonkar: conception of idea, manuscript preparation, reviewing manuscript, review of literature. SS, AKhalsa: data collection, reviewing manuscript.

Funding The authors have not declared a specific grant for this research from any funding agency in the public, commercial or not-for-profit sectors.

Competing interests None declared.

Patient consent for publication Obtained

Provenance and peer review Not commissioned; externally peer reviewed.

\section{ORCID iDs}

Srikanta Kumar Padhy http://orcid.org/0000-0002-0800-9961

Anup Kelgaonkar http://orcid.org/0000-0002-3983-4200

Suman Sahu http://orcid.org/0000-0002-9664-9554

\section{REFERENCES}

1 Hogan MJ, Alvarado J, Weddell J. Histology of the Human Eye. Philadelphia: WB Saunders Company, 1971

2 Hendrickson AE, Yuodelis C. The morphological development of the human fovea. Ophthalmology 1984;91:603-12.

3 Otani T, Yamaguchi Y, Kishi S. Improved visualization of Henle fiber layer by changing the measurement beam angle on optical coherence tomography. Retina 2011;31:497-501

4 Lujan BJ, Roorda A, Knighton RW, et al. Revealing Henle's fiber layer using spectral domain optical coherence tomography. Invest Ophthalmol Vis Sci 2011;52:1486-92.

5 Ouyang Y, Walsh AC, Keane PA, et al. Different phenotypes of the appearance of the outer plexiform layer on optical coherence tomography. Graefes Arch Clin Exp Ophthalmol 2013;251:2311-7.

Copyright 2021 BMJ Publishing Group. All rights reserved. For permission to reuse any of this content visit

https://www.bmj.com/company/products-services/rights-and-licensing/permissions/

BMJ Case Report Fellows may re-use this article for personal use and teaching without any further permission.

Become a Fellow of BMJ Case Reports today and you can:

- Submit as many cases as you like

- Enjoy fast sympathetic peer review and rapid publication of accepted articles

- Access all the published articles

- Re-use any of the published material for personal use and teaching without further permission

Customer Service

If you have any further queries about your subscription, please contact our customer services team on +44 (0) 2071111105 or via email at support@bmj.com.

Visit casereports.bmj.com for more articles like this and to become a Fellow 